\title{
Farmers Suicide in India: Issues, Challenges and Remedies
}

\author{
Anil Kumar, R. ${ }^{1 *}$ and Raghavendra, R.H ${ }^{2}$ \\ ${ }^{1}$ Department of Economics, Government First Grade College, Shiralakoppa-577428, Shikaripura Tq, Shimoga Dist, Karnataka \\ State, India \\ ${ }^{2}$ Department of Commerce, Government First Grade College, Shiralakoppa-577428, Shikaripura Tq, Shimoga Dist, Karnataka \\ State, India
}

Corresponding author: anil15624@gmail.com \raghavpondiuni@gmail.com

\begin{abstract}
The purpose of the study is to examine why Farmers suicide is a burning issue in India. Farmers are life savers then why they are killing themselves. Is there any nexus between farmers' suicide and government actions. Agriculture sector data like GDP for 1960-2016, Share of agriculture sector to GDP and disparities in Agriculture and Non agriculture income also agriculture census data from 1951 to 2011 were obtained. Study depicts about what NSSO and NCRB data says about farmers' distress in India. Doubling farmers' income by 2022-23 could become the only panacea for thwarting farmers' suicide in India comparison of agricultural income with non agricultural income also another area of study. In this way farmers suicide issues challenges and remedies has been discussed.
\end{abstract}

\section{Highlights}

(0) The study suggests that farmers need to be protected from falling into the trap of the spiralling debt, which is the primary risk factor for suicide. For this, farming must be protected from failure and made profitable.

Keywords: Farmer's suicide, Agrarian Distress, Sustainable Development, Irrigation, Agrarian crisis

"Man is guided by the stomach. He walks and the stomach goes first and the head afterwards. Have you not seen that? It will take ages for the head to go first".

- Swami Vivekananda

As Swami Vivekananda said in the above sentence the human beings are always dictated by the stomach per se. In India agriculture is a state subject it means the main responsibility of development of agriculture lies with the state only and the centre can provide resources to states to develop primary sector. under DPSP (directive principles of state policy) Our Constitution also says that it is the duty of the state to develop agriculture, articles 38 and 48 justifies this Article 38(2) says that the state shall, in particular, strive to minimise the inequalities in income, and endeavour to eliminate inequalities in status, facilities and opportunities , not only amongst individuals but also amongst groups of people residing in different areas or engaged in different vocations. Another article vividly mentions that the state shall endeavour to organize agriculture and animal husbandry on modern and scientific lines and shall, in particular, take steps for preserving and improving the breeds. No nation can afford to compromise with its farming and farmers. And much less India, wherein the absolute number of households engaged in agriculture in 2011 (119 million) outpaced those in 1951 (70 million).Then, there are the landless agricultural labour who numbered 144.30 million in 2011 as against 27.30 million in 1951. The welfare of this elephantine size of India's population is predicated upon a robust agricultural growth strategy that is guided by an income enhancement approach. 
CD Kumar and Raghavendra

\section{Research Questions}

1. Significance of agriculture in India

2. India's agriculture contribution to its GDP with respect to other sectors.

3. Main reasons for farmers' suicide in India

4. Is current funding for agricultural research is sufficient to attain sustainable development in agriculture?

5. Can Indian farmers double their income by 2022-23 (judging by present scenario)

\section{Review of Literature}

Ambedkar, D.B. (1918): “In short, strange as it may seem, industrialization of India is the soundest remedy for the agricultural problems of India. The cumulative effects of industrialization, namely a lessening pressure (of surplus labour) and an increasing amount of capital and capital goods will forcibly create the economic necessity of enlarging the holding. Not only will this, but industrialization, by destroying the premium on land, give rise to few occasions for its sub-division and fragmentation. Industrialization is a natural and powerful remedy, in this paper Ambedkar strongly suggested the ideas of Arthur Lewis theory of Theory of economic development.

Posani, B. (2009): Desperate indebtedness was found to be the common thread that ran through most of the reported suicides. Deeper analyses, however, reveal that indebtedness is only a symptom. According to this report the major causes for Agrarian Distress in India are small land holding, less institutional support, declining irrigation facility, relying more on mansoon, price shocks, credit squeeze, tradermoney lender Nexus and pervasive indebtedness. Indian agriculture today is 'the economic residue' that accommodates 'non-achievers', and that the principal motivation of the peasant today is to stop being a peasant Not an encouraging prospect, then, for the peasant movements, or the peasant.

Saritha, G. (2015): reviewed that the between 19972007 21,174 farmer's suicide reported in India, the major reason is indebtedness. In their case study they figured out these following results, the outbreak of suicide in India is appalling and on average one Indian farmer committed suicide every 32 minutes during the past period 1997to2007 and as many as 48 farmers suicide per day in India between 2002-2007. The farmer suicide in India as a clear indication of serve distress in the farming community. The causes for present agrarian distress vary from one to another state. But the genuine causes may be common in all states which include external trade liberalization and neo-liberal policy driven reforms in the economy have played havoc with the farm dependent population in the country. Indian state now acknowledges the fact that between 1993and2003, 1, 00,248 farmers committed suicide in India..The most important factor is debt.

Vasavi, A. (2005): focused on the relationship between commercial crops and suicides. Since the key sources of non-institutional creditors have been agri-business agencies (who provide both inputs at deferred credit to agriculturists and loans), and the new money lenders and creditors13, including relatives and friends who draw on their urban salaries, these debts pose a double burden on agriculturists. For one, interest rates are exorbitant (ranging from 24 to 45 percent per annum) and secondly they are linked to their personal and social networks. Inability to pay is often met with ridicule, ostracism or public humiliation. As several reports and case studies highlight, many of those who committed suicide did so after experiencing such humiliation or facing threats of dispossession of their assets.

Based on the above mentioned reviews the research gap has been found on the farmers' suicide. Hence the study has been made as follows.

\section{Significance of agriculture sector in India}

During the recent decade (2004-05 to 2014-15), crop, livestock and fisheries registered growth of 2.93, 6.11 and 5.13 per cent per annum, respectively. The pattern indicates that overall growth in agriculture moves parallel with the crop sector. The same is also confirmed from the year-on-year fluctuations in different sub-sectors.

Livestock sub-sector is growing at an appreciable and sustainable rate and is ahead among all subsectors. It is remarkable that the livestock sub-sector never attained a negative growth in any of the years during the span of last 34 years; the lowest growth rate attained in the sector was one per cent in the year 2003-04. Thus, the livestock sub-sector can be 
Table 1: Movement of Indian Economy: trends in GDP/GVA across sectors

\begin{tabular}{|c|c|c|c|c|c|c|}
\hline Period & 1960-61/ 1968-69 & 1968-69/ 1975-76 & 1975-76/ 1988-89 & 1988-89/ 1995-96 & 1995-96/ 2004-05 & 2004-05/ 2016-17 \\
\hline \multicolumn{7}{|c|}{ Average GDP @2004-05 prices (₹ Billion) } \\
\hline Agriculture & 1636 & 1955 & 2547 & 3473 & 4358 & $5771^{*}$ \\
\hline $\begin{array}{c}\text { Agriculture \& } \\
\text { Allied Activities }\end{array}$ & 2004 & 2401 & 3047 & 4116 & 5174 & 7126 \\
\hline Industry & 725 & 1000 & 1676 & 2958 & 4773 & 10021 \\
\hline Services & 1859 & 2517 & 4078 & 7286 & 13083 & 32454 \\
\hline \multicolumn{7}{|l|}{ Share $(\%)$} \\
\hline Agriculture & 35.66 & 33.03 & 28.94 & 24.19 & 18.92 & $12.72^{*}$ \\
\hline $\begin{array}{c}\text { Agriculture \& } \\
\text { Allied Activities }\end{array}$ & 43.68 & 40.57 & 34.62 & 28.66 & 22.47 & 11.63 \\
\hline Industry & 15.80 & 16.90 & 19.04 & 20.60 & 20.73 & 20.30 \\
\hline Services & 40.52 & 42.53 & 46.34 & 50.74 & 56.81 & 68.07 \\
\hline \multicolumn{7}{|c|}{ GDP growth rate (\% p.a.) } \\
\hline Agriculture & 0.7 & 2.19 & 2.74 & 2.69 & 2.23 & $3.88^{*}$ \\
\hline $\begin{array}{l}\text { Agriculture \& } \\
\text { Allied Activities }\end{array}$ & 1.04 & 2.24 & 2.47 & 2.76 & 2.28 & 3.43 \\
\hline Industry & 5.05 & 3.92 & 5.53 & 5.9 & 4.87 & 7.51 \\
\hline Services & 5.03 & 3.37 & 5.4 & 6.15 & 7.86 & 8.69 \\
\hline
\end{tabular}

Source: DFI Committee Estimates; Estimates for the period 2004-05 to 2016-17 are based on GVA *upto 2015-16 only.

relied upon for risk mitigation and minimizing the losses to the farmers in case of even worst outcomes from others sub-sectors and is likely to emerge as engine of growth of agricultural sector and. Previous studies have unanimously reported that livestock as the best insurance against agrarian distress as the sector is the source of sustained income and generates income more frequently than the crop sector.

Table 2: Percentage share of GDP at 2004-05 prices

\begin{tabular}{ccccc}
\hline Year & Agriculture Industry & Service & $\begin{array}{c}\text { Gross Domestic } \\
\text { product at factor } \\
\text { cost }\end{array}$ \\
\hline $2004-05$ & 19.0 & 27.9 & 53.0 & 100.0 \\
$2005-06$ & 18.3 & 28.0 & 53.7 & 100.0 \\
$2006-07$ & 17.4 & 28.7 & 54.0 & 100.0 \\
$2007-08$ & 16.8 & 28.7 & 54.4 & 100.0 \\
$2008-09$ & 15.8 & 28.1 & 56.1 & 100.0 \\
$2009-10$ & 14.6 & 28.3 & 57.1 & 100.0 \\
$2010-11$ & 14.6 & 27.9 & 57.5 & 100.0 \\
\hline
\end{tabular}

Source: Central Statistical Office.

The above data clearly shows that even though agriculture still a predominant job sector in India but its contribution to India's GDP is reducing year by year. In 2004-05 it was 19.0 percent but it reduced to 14.6 percent in 2010-11 where as service sector becoming major GDP contributor and industry sector maintaining sustainable growth.

Table 3: Disparities in Agriculture and NonAgriculture income

\begin{tabular}{cccc}
\hline Year & $\begin{array}{c}\text { Farmers } \\
\text { income per } \\
\text { cultivator (₹) }\end{array}$ & $\begin{array}{c}\text { Wage } \\
\text { earning per } \\
\text { agricultural } \\
\text { labour (₹) }\end{array}$ & $\begin{array}{c}\text { Income } \\
\text { per Non- } \\
\text { agriculture } \\
\text { worker }\end{array}$ \\
\hline $1983-84$ & 4286 & 1467 & 12,786 \\
$1987-88$ & 5653 & 2201 & 18,036 \\
$1993-94$ & 12,365 & 4784 & 37,763 \\
$1999-00$ & 24,188 & 8938 & 78,565 \\
$2004-05$ & 26,146 & 10,043 & 106,688 \\
$2011-12$ & 78,264 & 32,311 & 246,514 \\
\hline
\end{tabular}

Source: Doubling farmers income report vol 1.

The growth rate in per farmer income in this period was mere 1.96 per cent, which was the lowest during 1983-84 to 2011-12. The growth rate in per cultivator income accelerated to 7.29 per cent. Non agricultural income is rising rapidly when compare to agricultural income both in cultivators income and agricultural labours income. 
Y) Kumar and Raghavendra

Table 4: Total number of workers and share of Cultivators and Agriculture Laborers based on Agricultural Census

\begin{tabular}{cccccccc}
\hline & \multirow{2}{*}{$\begin{array}{c}\text { Total } \\
\text { workers } \\
\text { Million }\end{array}$} & Cultivators & $\begin{array}{c}\text { Agricultural } \\
\text { Labourers }\end{array}$ & Total & $\begin{array}{c}\text { Cultivators } \\
\text { in total } \\
\text { workers }\end{array}$ & $\begin{array}{c}\text { Agricultural } \\
\text { labour in total } \\
\text { workers }\end{array}$ & $\begin{array}{c}\text { Agricultural workers } \\
\text { in total workers }\end{array}$ \\
\hline 1951 & 139.5 & 69.9 & 27.3 & 97.2 & 50.11 & 19.57 & 69.68 \\
1961 & 188.7 & 99.6 & 31.5 & 131.1 & 52.78 & 16.69 & 69.48 \\
1971 & 180.4 & 78.2 & 47.5 & 125.7 & 43.35 & 26.33 & 69.68 \\
1981 & 244.6 & 92.5 & 55.5 & 148.0 & 37.82 & 22.69 & 60.51 \\
1991 & 314.1 & 110.7 & 74.6 & 185.3 & 35.24 & 23.75 & 58.99 \\
2001 & 402.2 & 127.3 & 106.8 & 234.1 & 31.65 & 26.55 & 58.20 \\
2011 & 481.9 & 118.8 & 144.3 & 263.1 & 24.65 & 29.94 & 54.60 \\
\hline
\end{tabular}

Source: Agricultural Statistics at a Glance various issues.

The above reveals that the Decade by decade depending on agricultue and allied activities increasing drastically in 1951 it was just 139.5 million but in 2011 its pegged at 481.9 million people. Another soothing point is the percentage of total population depending on agriculture is reducing for example in 195169.68 percentage of total population engaged in agriculture but in 2011 it is approximately 55 percentage.

\section{Brief History of Farmers' Distress in British India}

Historically the first revolt of 1857 (generally known as India's first war of independence ) saw the major peasants and land Lords uprisings namely sanyasi rebellion (1763-1800), Orissa zamindar's,1804-17; mysore peasants in 1830-31 peasants discontent against British authority was a familiar of the nineteenth century. Mainly four vital peasants struggled emerged viz., the kisan sabha and ektha movement in avadh in U.P., the mappila rebellion in Malabar; the Bardoli satyagraha in Gujarat and champaran satyagraha in Bihar.

After independence india's food production size is drastically reduced because of the division. The First five year plan gave the highest priority to agriculture, especially food production, by allotting 31 percent of the total plan outlay on agriculture. In The Third five year plan Green revolution was started in india. Later plans also stressed the need of developing agriculture sector. Between 1995 and 2004 over 150,000 farmer suicides were reported in India (Mishra 2007), and the number continues to grow at a disturbing average of 10,000 a year (BBC 2008).

\section{(a) Farmers suicide is divided into two categories in NCRB report}

1. 'Farmers/Cultivators' include persons whose profession is farming and who either cultivates his/her own land or who cultivate lease land with or without the assistance of agricultural labourers.

Under this category the following data are extracted from NCRB report :

A total of 12,602 persons involved in farming sector (consisting of 8,007 farmers/cultivatorsand 4,595 agricultural labourers) have committed suicides during 2015, accounting for $9.4 \%$ of total suicides victims $(1,33,623)$ in the country.

'Bankruptcy or Indebtedness' and 'Farming Related Issues' are reported as major causes of suicides among farmers/cultivators, accounting for 38.7\% $(3,097$ out of 8,007 suicides) and $19.5 \%$ (1,562 out of 8,007 suicides) of total such suicides respectively during 2015. The other prominent causes of farmer/ cultivators suicides were 'Family Problems' (933 suicides), 'Illness' (842 suicides) and 'Drug Abuse/ Alcoholic Addiction' (330 suicides), accounting for $11.7 \%, 10.5 \%$ and $4.1 \%$ of total farmers/cultivators ' suicides respectively. During 2015, major causes of suicides among male farmers/cultivators were reported as 'Bankruptcy or Indebtedness' (2,978 suicides) and 'Farming Related Issues' (1,494 suicides), which accounted for $39.4 \%$ and $19.7 \%$ of total male farmers/cultivators suicides respectively. Similarly in female farmers/cultivators Suicides, 'Bankruptcy or Indebtedness' followed by 'Family Problems', were major causes of suicides, accounting 
for $27.0 \%$ (119 out of 441 suicides) and 18.1\% (80 suicides) of total suicides by female farmers/ cultivators respectively during 2015. 'Farming Related Issues' and 'Illness' both accounted for $15.4 \%$ (68 suicides each) during $2015.42 .7 \%$ suicides in Maharashtra (1,293 out of 3,030 suicides), 79.0\% in Karnataka (946 out of 1,197 suicides) and 46.5\% suicides in Telangana (632 out of 1,358 suicides) were due to 'Bankruptcy or Indebtedness'. 31.5\% suicides in Madhya Pradesh (183 out of 581 suicides) were due to 'Family Problems'.

2. Agricultural Labourers' are those persons who primarily work in farming sector (agriculture/horticulture) and whose main source of income is from agricultural labour activities.

A total of 4,595 agricultural labourers have committed suicides during 2015.Out of 4,595 suicides committed by agricultural labourers during 2015, 4,018 were male and 577 were female. State/UT-wise analysis reveals that majority of such suicides were reported in Maharashtra (1,261 suicides) followed by Madhya Pradesh (709 suicides), Tamil Nadu (604 suicides), Andhra Pradesh (400 suicides), Karnataka (372 suicides), Gujarat (244 suicides) and Kerala (207 suicides), these States together accounted for $82.6 \%$ of total such suicides (3,797 out of 4,595 suicides) in the country during 2015. Goa, Manipur and West Bengal and all UTs (except Puducherry) have reported nil incidents of agricultural labourers suicides during 2015.

\section{(b) Causes of Suicides among Agricultural Labourers}

'Family Problems' followed by 'Illness' are reported as major causes of suicides among agricultural labourers, accounting for $40.1 \%(1,843$ out of 4,595 suicides) and $19.0 \%$ (872out of 4,595 suicides) of total such suicides respectively during 2015 . The other prominent causes of suicides among agricultural labourers were reported as 'Drug Abuse/Alcoholic Addiction' (312 suicides), 'Poverty' (178 suicides), 'Bankruptcy / Indebtedness from Financial Institutions' (155suicides), 'Bankruptcy/ Indebtedness from Non-Financial Institutions/ Money Lenders' (100 suicides), 'Property Disputes' (93 suicides) and 'Marriage Related Issues (Dowry, Non-settlement of marriage, Divorce etc.)' (90 suicides), accounting for $6.8 \%, 3.9 \%, 3.4 \%, 2.2 \%$, $2.0 \%$ and $2.0 \%$ of total such suicides respectively.

\section{(c) Is small and marginal land holding is also a main reason for farmers suicide in India?}

In India farmers are divided on the basis of their land holding status, farmers have been classified in four categories namely 'Marginal Farmers/ Cultivators' (having less than 1 hectare of land), 'Small Farmers/Cultivators' (having 1 hectare to below 2 hectare of land), 'Medium Farmers/ Cultivators' (having 2 hectare to below 10 hectare of land) and 'Large Farmers/Cultivators' (having more than 10 hectare of land).

NCRB data on farmers suicide in India is revealed that Land holding status of farmers/cultivators who committed suicide during 2015 revealed that $45.2 \%$ and $27.4 \%$ of total such victims were 'Small Farmers/Cultivators' $(3,618)$ and 'Marginal Farmers/ Cultivators' $(2,195)$ respectively, these together accounted for $72.6 \%$ of total farmers/cultivators' suicides $(5,813$ out of 8,007$)$. Out of 2,195 suicides committed by 'Marginal Farmers/Cultivators', 834 and 354 such suicides were reported in Maharashtra and Chhattisgarh, accounting for $38.0 \%$ and $16.1 \%$ of total such victims respectively during 2015. Among suicides committed by 'Small Farmers/ Cultivators', $35.5 \%$ and $20.1 \%$ were reported in Maharashtra $(1,285$ out of 3,618$)$ and Karnataka (751 out of 3,618) respectively. A total of 160 'Large Farmers/Cultivators' have committed suicides in the year 2015, among them majority incidents were reported in Telangana (79 suicides) and Chhattisgarh (37 suicides). Another recent report doubling farmers income by 2022-23 also revealed that 'the Smallholders' share (58.4 to 76.44 per cent) in climate vulnerable states is very less as compare to low income states (78.55 to 96.92 per cent) because of adverse impact of climate will be more on small holding farmer.

At all India level, the percentage of indebted agricultural households increased with size class of land possessed between 41.9 percent in the lowest size class of land possessed and 78.7 percent among agricultural households possessing $10.00+$ ha. land. The average amount of outstanding loan also increased with the size class of land possessed except for the lowest size class $(<0.01$ ha.) where the average outstanding loan amount was slightly 
DP Kumar and Raghavendra

higher than that of the next lowest size class of land possessed. (The NSSO survey 2012 -13, report no.576)

The NSSO survey 2012 -13 (report no.576) revealed that about 52 percent of the agricultural households in the rural India were estimated to be indebted at the time of the survey. The average amount of outstanding loan per agricultural household was estimated approximately as ₹ 47000 .

Recently, Maharashtra government had informed the State Assembly that 639 farmers had committed suicide, and among the reasons cited were crop failure, debt and inability to pay back loans. (between March and may 2018)

\section{(d) Investment on Research and development}

Agriculture has made significant strides following the technological advancements initiated during the sixties and the seventies of the last century. The transformation of India from food deficiency to selfsufficiency and from a net importer to a net exporter of agricultural commodities is a matter of great pride. In fact, the outcomes have been incredible, as the country now (2017-18) boasts of producing about 276 million tonnes (mMt) of foodgrains, 300mMt of horticultural crops, $164 \mathrm{mMt}$ of milk, and $11 \mathrm{mMt}$ of fish. Unequivocally, the budgetary outlays allocated towards the development of scientific infrastructure and human resources in the past have paid rich dividends.

However, a deceleration in the rate of productivity growth experienced from the last decade (2000s), along with technology fatigue, will soon jeopardise such gains unless the country make adequate investments in Agri-R\&D, and also the approach is reoriented to meet the new challenges. The allocations to the National Agricultural Research System (NARS) under the aegis of the Indian Council of Agricultural Research (ICAR), State Agricultural Universities (SAUs), and other organisations have largely been constricted. India spent Rs 6,238 crore on Agri-R\&D in 2016-17, which is even less than 0.5 per cent of the total income earned from agriculture and allied activities, i.e. gross domestic product. The expenditure on Agri-R\&D in India has been hovering around 0.3-0.4 per cent of Agri-GDP since 2001, except in 2011 when it registered 0.52 per cent share because of higher plan allocations of the
Union government. The allocations are minuscule in most of the poorer states situated in the eastern region of the country. The amount spent on AgriR\&D is substantively lower in comparison to many developed countries, and also when seen vis-a-vis comparable developing economies. The share of Agri-GDP is much higher in Brazil (1.8 per cent), Mexico (1.05 per cent), Malaysia (0.99 per cent) \& China (0.62 per cent); and in the high income countries it stands at 3.01 per cent.

The comparison of agricultural research funding for the year 2011-12 for India with other developing countries. China spends nearly 9,366 million 2011 PPP dollars on agricultural research and the intensity of funding (funding as percentage of AgGDP) has reached 0.62 per cent of AgGDP (Pal, 2017). Further, against 10,242 FTE (Full-Time Equivalent) scientists in India China has got around 43 thousand FTE scientists.

Table 5: International Comparison of Agricultural Research Funding, 2011-12

\begin{tabular}{ccccc}
\hline $\begin{array}{c}\text { S1. } \\
\text { No. }\end{array}$ & Country & $\begin{array}{c}\text { Number of } \\
\text { scientists, } \\
\text { Full-time } \\
\text { equivalent }\end{array}$ & $\begin{array}{c}\text { Funding } \\
\text { in million } \\
\text { 2011 PPP } \\
\text { dollars }\end{array}$ & $\begin{array}{c}\text { Research } \\
\text { intensity } \\
\text { (\%) }\end{array}$ \\
\hline 1 & Brazil & $5,869.4$ & $2,704.0$ & 1.8 \\
2 & Bangladesh & $2,121.0$ & 250.6 & 0.4 \\
3 & China & $43,000.0$ & $9,366.0$ & 0.6 \\
4 & Malaysia & $1,609.4$ & 592.3 & 1.0 \\
5 & Pakistan & $3,678.3$ & 333.0 & 0.2 \\
6 & Sri Lanka & 618.8 & 61.8 & 0.3 \\
7 & South Africa & 746.3 & 294.5 & 2.0 \\
8 & India & $10,242.0$ & $3,533.0$ & 0.4 \\
\hline
\end{tabular}

Source: Pal (2017).

The recent study by Pal (2017) reported that research and development for the Indian agriculture has so far responded well to the national challenges; now the basic thrust must be for developing local capacity to carry forward the findings at the top level so that the people at the grass root level will harness the maximum benefit from these researches. The system is to be developed in such a way that it not only complies with international commitments and scientific principles but also seeks participation of stakeholders and incorporates social voice in decision-making along with the consideration of development challenges at different levels like 
efficient and inclusive development, sustainability of natural resources, nutritive and value products, environmental safety, etc., which are sometimes cumulative and conflicting needing more research resources and their targeting.

\section{Finding Remedy}

\section{Implementing Swaminathan report on agriculture (National Commission on Farmers -2004 to 2006) recommendations}

According to Swaminathan committee report, the major causes of the agrarian crisis are: unfinished agenda in land reform, quantity and quality of water, technology fatigue, access, adequacy and timeliness of institutional credit, and opportunities for assured and remunerative marketing. Adverse meteorological factors add to these problems. Agrarian distress has led farmers to commit suicide in recent years. The committee also suggested some remarkable measures to strengthen Indian agriculture sector viz.,Farmers need to have assured access and control over basic resources, which include land, water, bioresources, credit and insurance, technology and knowledge management, and markets. The NCF recommends that "Agriculture" be inserted in the Concurrent List of the Constitution. Along with these suggestions committee also suggested five main components: soil health management; water harvesting and Sustainable and equitable use of water; access to affordable credit and crop and life insurance reform; development and dissemination of appropriate technologies and improved opportunities; infrastructure and regulation for marketing of agricultural produce.

Improving areas of agriculture are:

(a) Extension of irrigation facility.

(b) Extensive use of modern agricultural technology.

(c) Increasing the both public and private investment on agriculture.

(d) Effective implementation of land reforms.

(e) More institutional credit support. Getting farmers loans from the state owned banks at very low interest rates.

(f) Marketing reforms.

(g) Thwarting the further division of land.

\section{CONCLUSION}

Concerns about farmer suicide are not new, and studies on the subject have suggested different explanations for the act, India is an agrarian country with around $70 \%$ of its people depending directly or indirectly upon agriculture. Farmer suicides account for $11.2 \%$ of all suicides in India. Activists and scholars have offered a number of conflicting reasons for farmer suicides, such as high debt burdens, poor government policies, corruption in subsidies, monsoon failure, public mental health, personal issues and family problems. The present study says that economic planning would be a failure unless agricultural production is raised rapidly. The agriculture and allied sector continues to be crucial to the sustainable development and development of the Indian economy, not only does it meets the food and nutritional requirement of 1.3 billion Indians, but also contributes significantly to secondary and tertiary sectors. Hence, the study suggests that farmers need to be protected from falling into the trap of the spiralling debt, which is the primary risk factor for suicide. For this, farming must be protected from failure and made profitable. In this way certain issues challenges and remedies has been discussed briefly.

\section{REFERENCES}

Ambedkar, D.B. 1918. Small Holdings in India and their Remedies. Journal of Indian Economic Society, 1: 1-24.

Commission, P. 1981. $6^{\text {th }}$ Five Year Plan. Retrieved March 25, 2018, from http://planningcommission.nic.in:

Vasavi, A. 2005. Suicides and the Making of India's Agrarian Distress. Agrarian Distress and Farmers' Suicides in India (pp. 1-17). Acharya Nagarjuna University, Guntur: Centre for Economic and Social Studies, Hyderabad.

Sanyal, K. 2006. Report Summary Swaminathan Committee on Farmers (October 2006). Retrieved march 04, 2019, from https://www.prsindia.org: https://www.prsindia.org/sites/ default/files/parliament_or_policy_pdfs/1242360972-final\%20summary_pdf_0.pdf

Chandana, R.C. 2006. 'Population Geography, Concepts, Determinants, and Patterns',. New Delhi: Kalyani Publishers.

Posani, B. 2009. Crisis in the Countryside: Farmers Suicides and Political Economy of Agrarian Distress In India. London School of Economics and Political Science, Development studies Institute working papers, pp. 1-52.

Basu, D.D. 2012. Introduction to the Constitution of India. Gurgaon: Lexis Nexis Butterworths Wadhwa.

Paul Adamson, K.K. 2012. Are marginalized women being left behind? A population based study of institutional births in rural 


\section{Kumar and Raghavendra}

India. Department of Epidemiology, Florida International University.

India, G.O. 2013. Income Expenditure Productive assets and indebtedness of Agricultural households in India. New Delhi: Ministry of Statistics and Programme Implementation, Govt of India.

India, P. C. 2013. Twelfth Five Year Plan (2012-2017) Economic Sectors. New Delhi: SAGE Publications India Pvt. Ltd.

Saritha, G. 2015. Agrarian Crisis and Farmers Suicides In India A Case Study of Andhra Pradesh. International Journal of Multidisciplinary Advanced Research Trends, pp. 18-24.
NCRB. 2010 -2016. Farmers suicides. Retrieved January 19, 2019, from https://data.gov.in: https://data.gov.in/search/ site?query $=$ farmers \& page $=2$

India, G.O. 2017. Agricultural Statistics at a Glance 2016. New Delhi: Ministry of Agriculture \& Farmers Welfare, Department of Agriculture, Cooperation \& Farmers Welfare.

Mahajan, G.D. 2018. Indian Economy. New Delhi: S Chand.

India, G. o. (2019). Economic Survey 2018-19. Retrieved April 12, 2019, from www.indiabudget.gov.in: https://www. indiabudget.gov.in/indexst.asp 